\title{
University libraries and students of low socio-economic status in Nigeria
}

\author{
David T. Aju, PhD \\ Senior Lecturer \\ Department of Library and Information Science \\ Benue State University, Makurdi, Nigeria \\ E-mail: ajudave@yahoo.com \\ Comfort M. Tyopev \\ Assistant Librarian \\ University Library and Information Services \\ Benue State University, Makurdi, Nigeria \\ E-mail: cmtyopev669@gmail.com \\ Simon Ternenge Tofi, CLN \\ Librarian II \\ Benue State School of Nursing, Makurdi, Nigeria \\ E-mail: ternengetofi@gmail.com
}

\begin{abstract}
The paper examined the roles of university libraries for students of low socio-economic status in Nigeria. The authors are extremely concerned about the plight of this cluster of university students because we have travelled this road before. Concepts were identified and discusssed. University libraries from the discussion were seen as hub of academic activities of universities with a number of functions. The paper however believes the plight of students from low socio-economic background was not properly covered by the operations of university libraries in Nigeria and as such they are disadvantaged. The authors feel this segment of students are important to be cared for because of their future survival, academic performance and achievement, they constitute the population of Nigeria and they may turnout to be leaders of tomorrow. In view of this, the article suggested support from university libraries for the students, university libraries should engage students from low socio-economic status in extra academic activities such as ICT drill, writing competition organize seminar sessions etc.
\end{abstract}

Keywords: Socio-economic status, Academic libraries, Students, Nigeria.

\section{Introduction}

The issue of fuctions of university libraries in Nigeria is a perennial problem. Given universities objectives, vision, mission and the complexity of courses offered, the influx of students population and the dynamics of the global society's demand with regard to service delivery of university libraries is worrisome. Most disturbing is the issues of ethnography, poor economy, ethnicity and the plight of students of low socio-economic status in universities in Nigeria; given the economic realities, a situation where the Nigerianeconomy is depressed, education and the education of citizens is no more the priority of government. This paper is focus on roles of university libraries in Nigeria as it is obtained in university libraries in developed countries of the world.

\section{Conceptual clarification and discussion university libraries:}

University libraries are established to support academic activities within and university's link with other universities with regard to provision of information materials and services. In an attempt to perform these roles, a university library select, acquire, organise, preserve and 
David T. Aju, Comfort M. Tyopev and Simon Ternenge Tofi: University libraries and students of low socio-economic status in Nigeria

disseminate information materials owned by her to its potential patrons.

Scholars such as Edoka (2000), Nwachkwu and Asiegbu (2014), Aguolu and Aguolu (2002), Aju (2014) have listed the general functions of university libraries in their various works as follows:

a) To provide require information resources in connection with faculty needs and research students.

b) To provide specialized information resources and services to segments of wider community.

c) Provide information materials for personal and self development of patrons within the university community.

d) To provide protection and security for all information materials stock (print and non-print ones).

e) Provide information materials required for academic programmes of the university.

f) Provision of resources in support of faculty, external and collaborative resources.

g) Provision of materials in support of postgraduate research.

h) Manage user education programmes by providing instructional support materials for the university.

\section{Students of low socio-economic status}

The concept or phrase low socioeconomic status can better be described than a definition for it. Students of low socio-economic status are undergraduates from families whose income is low, the parents are mostly farmers or self employed, government worker or an NGO employee in Nigeria. For the university library to fulfil the above roles, it is assumed that the patrons (students) are on a level socio-economic playing ground but if one observed carefully, one would appreciate the fact that majority of the students are from the low socio- economic strata especially those from public owned universities. They come from families whose economic and social standing is low, in that light, students from such background can hardly afford relative expensive textbooks, ipad, not a fairly used laptop. This is because the students and their parents income is low. This situation is common among many families in Nigeria as bustressed by Nyam, (2015) that most parents in Nigeria cannot afford the basic necessities of life, such as food, shelter and good health. In low income families, parents engage their children and wards in farming (subsistence), hawking all kinds of items of lifehood such as water, mangoes, vegetables, firewood etc. It is also common to find male students from the low socieconomic status on the streets riding motorbikes for the purpose of generating money for themselves and at times for their families. The story is not different, the female students from the low socio-economic status are also into all sought of unwholesome trades just to make life meaningful- this is just the tip of the iceberg.

This is the Nigerian situation, in many countries around the globe the problem of low socio-economic status is experienced, for instance, UNICEF, Regional office for central and Eastern Europe, Commonwealth of Independent States and Baltic States 2015 provide an informing report titled "Women and gender in countries in transition: a UNICEF Perspective". The report $\mathrm{x}$-rayed the disposition of women and children to increased unemployment, reduction in the value of family income, reductions in family subsidies and welfare allowances, reductions in free health care and less opportunities for higher education. This picture is a true situation in Slovakia, Romania, Armenia, Belarus and many other nations in Asia as maintained by 
David T. Aju, Comfort M. Tyopev and Simon Ternenge Tofi: University libraries and students of low socio-economic status in Nigeria

the report.With the above scenario in Nigeria, the plight, zeal, interest and the willingness of students of low socio-economic status is defeated as far as standard education is concerned. Unfortunately, as observed by Aina, Adigun and Ogundipe (2011), there is dearth of libraries in the true sense of it in Nigeria. They all submitted that where libraries are available, they are poorly funded and poorly stocked with information materials. The condition of libraries in public universities is same for the fact that the economy is depressed and funds are not released from National Universities Commission(NUC) a fact we cannot substantiate.

As earlier reported, it is not certain if the fourth Sustainable Development Goals (SDGs) will be achievedin Nigeria and other countries of the world? In the 21 st century, the world is operating a system whose activities, methods of operation and relationships are dependent on information which can be obtained from university libraries among other information sources. Given the exigency of the $21 \mathrm{st}$ century, university libraries in Nigeria are bracing up for emerging trends. For instance, Information and Communication Technologies (ICTs) are relatively new in many university libraries in Africa with its associated challenges. At the moment, a number of university libraries in Nigeria are struggling with automation, internet service provision, migration protocol, purchase of software packages, OPAC operation, securing information resources in stock, use of the emerging technologies and softwares.

\section{Low social-economic status students' targetted roles of university libraries}

As earlier mentioned, university library is the hub of academic operation of any university with complex and sophisticated clientele and multi- functions. However, with the emerging trends, technologies and the influx of students population in universities in Nigeria including students from low income families, the roles of university libraries has increased with the following specific functions:

1. ICT drill in university libraries: Ujoumunna et al (2017), Fabunmi (2014), Igwe et al (2017) in their seperate works dwelled extensively on ICTs as tools university libraries mostly use to deliver their assigned mandate. Whatever is said of ICT in university libraries, the critical success factor is training of staff and "end users" in universities. Most library staff and users (students and lecturers) have little or no familiarity with internet and other ICT components thus the problem of non-use or resistance is among students, library staff and other users. Therefore, universities need not assume that users are conversant with information and communication technologies of their libraries. It is necessary that, their role will be to prepare and put in place end-user support systems especially for students from the low socio-economic strata, who in the true sense have never had an encounter with computers and other technologies such as CD-ROM, Slide, projectors, use of OPAC, etc.

Oketunji (2002) earlier suggested strategies for "end user" support to include regular consultation of users and induction of students on the benefits to be derived from the new technologies. Oketunji further maintained that such 
David T. Aju, Comfort M. Tyopev and Simon Ternenge Tofi: University libraries and students of low socio-economic status in Nigeria

efforts could enhance search and retrieval capacity of the users as well as generate learning motivation, he suggested selective dissemination of information and generation of an informed information bulletin by all university libraries in Nigeria. It also important that academic planning units of universities in Nigeria encooperate ICT related activities into all academic programmes of their universities.

This paper solicit for ICT drill for all students identified with low ICT skills in all Nigerian universities presumably students of low socio-economic status. This exercise can be conviniently put in place with the basic understanding of library management, students, and their departments timetable. This approach is based on the fact that librarians, by their training and professional practice are to extend the frontiers of knowledge.

2. Co-operative learning strategy: Apart from the above, Obida and Idoko (2019) suggested for co-operative learning strategy as an effective pedagogical tool in Nigerian learning environment. According to the authors, co-operative learning strategy could stimulate positive interdependence, equal participation, individual and group accountability, simultaneous interaction and group processing. Librarians as educators can use co-operative learning strategy in university libraries for students who are not knowledgeable of the composition of the library, library materials, use of information materials including ICTs, most especially students who are from the low socioeconomic status who avail themselves for this services.

3. Organize talk shows for students of low socio-economic status in Nigerian universities: Further, the university library mamnagement, through an appropriate committee could organise talk shows on cooperative learning and other important programmes of the library with a view to enhance use of the library in collaboration with faculties, departments, units and centres. The essence of that should be to deepenned discourse on the cooperative learning and use of library resources.

Nigerian system of education and products of the system are globally rated low. The universities and lecturers are blamed for the failed system. But if one is patient, it is easy to probe into the causes of this. There are overwhelming evidences and large scale assessment studies to this effect (Okiy, 1998 \& 2005).

University libraries are poorly funded, resources are poorly stocked for the fact that funds are not provided by the proppriators (states and the federal governments). This picture presented is disturbing because the library of a university is the hub on which all other academic activities revolve on.

4. Collaboration with institutional curriculum framework: 
David T. Aju, Comfort M. Tyopev and Simon Ternenge Tofi: University libraries and students of low socio-economic status in Nigeria

University libraries can make their impact felt through the institutional curriculum framework by lobbying their way through the university managements, deans, directors by writing attractive proposals to enrich academic programmes of the universities. This can be very rewarding and a credit for the university libraries, the university libraries could as well initiate reading/ writing competition programmes for faculties, the result can be published in bulletin or journals of the university. This in developed countries is not new among university libraries. Management of university libraries could award scholarship or provide other incentives for students who may emerge in the competitions mentioned above. Apart from that, it is believe that the reading or writing competition could encourage many students from low socio-economic strata to become academically very strong/ vibrant inspite of their families background.

5. Provision of enabling services: We consider it the responsibility of university libraries to render enabling services to their clientele which are for now overlooked. This could ensure maximum utilization the university library resources. Such services includes: issuance of library guide or other Library Brochure. These could assist students needing help on bibliograhic citation and other documentation. Another enabling services we recommend as role of university libraries is literature search, most students spend alot of their time in libraries searching information materials on the shelves by means of trial and error. This approach in many cases end up frustrating the students-thereby discouraging them from making the library their first point of search for information. The indigent students should be the priority of this service.

6. Organize seminar sessions: University libraries as nexous for academic activities should institute seminar sessions for all staff to brainstorm on current issues, trends emerging technologies and innovations in librarianship. This strategy is practiced in other fields including the medical profession. Seminar sesssions could create opportunities for re-evaluation of policies or services provided by the libraries especially as it affects the user community as well as a platform for feedback.

7. Collaboration and linkages services: Managements of university libraries are statutory responsible for the managementof libraries, they can lobby university managements for collaborations and linkages with libraries in advanced countries such as the UK, USA, Canada, etc. Libraries such as the Canadian libraries, library of congress and other tiger libraries have their hands opened for collaborations and linkages services with libraries in the third world countries without 
David T. Aju, Comfort M. Tyopev and Simon Ternenge Tofi: University libraries and students of low socio-economic status in Nigeria

stringent or rigid caveat attached to it.

Linkages and collaborations are capable of attracting funds, sponsorship and provision of resources and training. These efforts will go a long way and enrich university libraries in Nigeria and to an extend benefit students of low socio economic status_as users.

\section{Conclusion}

This paper dwelled on the roles of university libraries for the students of low socio-economic strata in Nigeria. Related concepts were explained with relevant examples, such as students of low socio-economic status, university libraries and their functions. The plight of students of low socio-economic status in universities is considered important because their future survival, academic performance and academic achievement is blinking. This segment of students whose socio-economic status is low constitute a huge proportion of national population. Inaddition, these are youths and leaders of tomorrow, so if they are not properly nurtured, the Nigerian society will suffer greatly. It is in this light that these authors felt university libraries need to urgently rescue them through their operations in universities. Such roles or operationsmay include cooperative learning programmes, engaging students in reading competition/ writing proposals as well as provide training support in form of ICT drill for students in Nigerian universities.

The following is the way forward:

a) Librarians working in university libraries should be visionary and supportive to students of low socio-economic status in their libraries through the provision of relevant information/ materials and services.

b) Management of university libraries should always lobby for support for their intending innitiatives for students.

c) University libraries should collaborate with faculties, departments, centres and units in their universities through their institutional curriculum framework by initiating attractive academic programmes. This may impact positively on the students and the perception on university libraries may also change.

d) University libraries should encourage students of low socio-economic status by providing incentives or rewards appropriately so that in the long run, the recalcitrant ones may as well avail themselves with the opportunities that abound in university libraries.

\section{References}

Aguolu, C.C. \& Aguolu, I.E. (2002). Libraries and information management in Nigeria: Seminal Essays on themes and problems. Maiduguri: ED-LINFORM Services.

Aina, A.J., Ogungbeni, J.I., Adigun, J.A. \& Ogundipe, T.C. (2011). Poor reading habits among Nigerians: The role of libraries. Library Philosophy and Practice (e-journal). Retrieved from https://dig italcommons.unl.edu/cgi/vie wcontent.cgi article $=1560 \&$ context=libphilprac.

Aju, D.T., Shidi, H. \& Ashaver, D. (2014). Types of libraries and their functions. In D.T. Aju and U. Karim (eds.). Groundwork on the use of 
David T. Aju, Comfort M. Tyopev and Simon Ternenge Tofi: University libraries and students of low socio-economic status in Nigeria

library, study skills and information communication technology (ICT). Makurdi: Bookworks publishers.

Alagu, A. \& Thanuskodi, S. (2018). Assesment of information literacy skills among students of Alagappa University, India. Library Philosophy and Practice (ejournal). Retrieved from https://digitalcommons.unl.e du/libphilprac/2083/.

Edoka, B.E. (2000). Introduction to library science. Onitsha: Palma Publishing and links company limited. p.119.

Fabunmi, S.O. (2014). Factors influencing use of internet by students of Adekunle Ajasin University , Akungba-Akoko Ondo state, Nigeria. Benue Journal of Library, Management and Information Science, 4(1): 99-111.

Nwanchukwu, V.N. \& Asiegbu, F.N. (2014). User education : An essential service of academic libraries in Nigeria. International Journal of Education Research, 13(1): 197-210.

Nwanko, F.O., Abubakar, A.L., Nene, T.H., Igwe, C.O. \& Abubar, G. (2017). Information technology service provision in technical vocational education and training: Implication for sustainable development in 21 st century Nigeria. Benue State University Journal of Education, 17(3): 108-116.

Nyam, S.S. (2015). The school library and promotion of reading culture. Delta
Library Journal, 9(1\&2): 40-45.

Obida, J.A. \& Idoko, F.A. (2019). Co-operative learning strategy: An X-ray of efficacious pedagogic tool. Benue State University Journal of Education (BSUJE), 19(1): 56-61.

Obugu, J.O. \& Okiy, R.B.(2011). Sources of funds in academic libraries in Delta State, Nigeria. Library Philosophy and Practice (ejournal). Retrieved from https://digitalcommons.unl.e du/libphilprac/676/.

Oketunji, I. (2005). Computerization of library operation: Necessary considerations. Proceedings of selected papers of the cataloguing, classification and indexing section of the Nigerian Library Association.

Okiy, R.B. (1998). Nigerian university libraries and the challenges of information provision in the $21 \mathrm{st}$ century. Library Bulletin, 3(1\&2), 17-18.

Okiy, R.B. (2005). Strengthening information provision in Nigerian university libraries through ICTs. The Electronic Library, 23(3), 311-318.

Ujoumunna, J.C., Okai, J.D., \& Unagha, A.M. (2017). Knowledge Management: A call for paradigm shift in library and information science education for a sustainable development in Nigeria. Proceedings of the 19th National Conference of the Nigerian Association of Library and Information Science Educators 29th 
David T. Aju, Comfort M. Tyopev and Simon Ternenge Tofi: University libraries and students of low socio-economic status in Nigeria

October- 1st November,

2017 held at Federal

Polytechnic Nekede,

Owerri, Nigeria.
UNICEP (2015). Woman and gender in countries in transition: UNICEP Perspective New York: 10017 